\title{
Modeling and Optimization of Supplier Selection Process for Decreasing Total Cost of Projects
}

\author{
Caner BAŞARAN \\ Department of Engineering Management, Middle East Technical University, Ankara, Turkey and \\ ASELSAN A.Ş., REHIS Business Sector, Ankara, Turkey
}

\section{Abstract}

There are significant factors affecting the decisions about supplier selection for procurement in steel construction firms: parts prices and transportation costs, payment periods, parts lengths and considering penalty terms coming from firm's clients. Therefore, in order to select optimal firms, each proposal must be considered on equal terms. As a result, 'Net Present Value' should be calculated in evaluating payment period, lead time, parts lengths and also transportation costs payment period. This evaluation may bring about decrease in costs of parts based on older procurements.

For an optimal solution, a mathematical model which includes, demand of units, net present value of products, delay cost due to retardation of Project is required. Moreover, the possibility of making predictions for future scenarios may assist in mapping out a route for the decision makers in steel construction firms. On this account, this study is designed to develop a mathematical model for the supplier selection system using integer programming.

Keywords: Optimization of Supplier Selection, Integer Programming Model, Joint Procurement, Vendor Selection

\section{Introduction}

Procurement is an increasingly important activity among variety of global companies. It is known that, many firms prefer procurement instead of production, in aim to focus on core of their business and allocate time for innovation and $\mathrm{R} \& \mathrm{D}$ activities. In the private sector, procurement is viewed as a strategic function working to improve the organization's profitability. In this direction, steel construction firm's purchasing expenses have been increasing for the last five years and it is assumed that expenses will continue to increase. The results of a recent progress report indicate \%15 increase in purchasing expenses only for mechanical parts. So, there is a need for a model that help in reducing the expense of purchasing. So, the main aim for this project is creating a supplier selection model that is used after accepting a project for steel construction firms. This model will be used in receiving the necessary material from qualified supplier. Moreover, this model could be the basis of a supplier selection decision support system. Growing company needs planned and applicable procurement. Below chart displays the process among related departments for procurement process. 


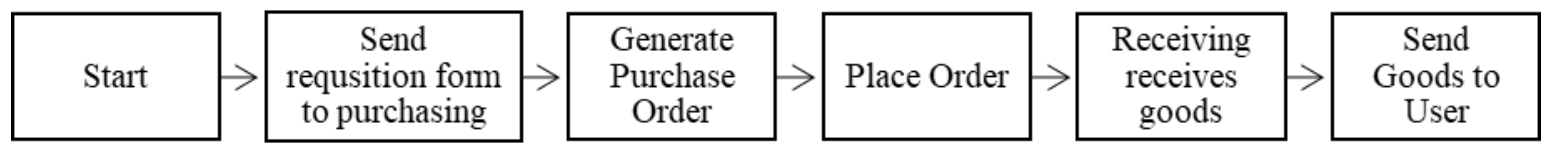

Figure 1: Purchase Requisition Flow

As seen in Figure 1, considering cost efficiency, buyer deals with generate purchase order through requisition process. When a project is activated in a steel construction firm, the need arises for steel angles or profiles. Creating requisition performed by planning department. Offers are taken from qualified suppliers. Generally, 60 is accepted as a satisfied score for asking an offer. Quality evaluations are not done in detail by purchasing department. Information related to quality scores is taken from quality department. Table 1. Below, shows each supplier's quality score. As seen below table, there are fifty-nine approved supplier. Only three firms were below sixty score in year 2014. Place Order performed by purchasing department. Offers mainly consist of price and lead time. In addition, Offers consist of transport type, date of maturity, products' lengths and product standard.

Two factors: Lead time and price are widely considered in procurement department. On the other hand, other agents: payment period, transportation cost and decrease of value of money resulting from lead time, transportation payment period and goods price payment period are associated with parts of price. Thus, purchasers should consider not only lead time and price but also other significant factors when exposed to requests for proposals, despite proposals seem to be definite. Moreover, considering the fact that, products which firm purchases have unique lengths and also firm can shorten the products which are longer than the required height. Also, considering the fact that, some firms may offer lower prices for their product which is longer than the required product compared to other firms' that offer higher prices for their shorter product. Moreover, client of firm may put penalty constraint for delay. Considering the fact that this penalty may sometimes be cost effective when product is cheaper than other firms' offers. It becomes obvious that two factors (lead time and price) are necessary but not sufficient agents of an effective procurement management.

In this regard, purchase method was analyzed and explained in the overview of procurement activities section. After that, literature review was conducted. On the basis of the literature reviewed, it has been observed that the basic methods for supplier selection. Subsequently, a mathematical model was created to work with certain assumptions. The mathematical model of the current project was run using gams program for selected six materials. Finally, the mathematical model of the current project was run using gams program for these materials and analyzed the results. 


\section{Literature Review for Supplier Selection}

\subsection{Criteria for Supplier Selection}

The main parameters used by companies in their supplier selection are as follows:

- Price

- Quality

- Delivery

- Performance History

- Production Facilities and Capacity

- Technical Capability

- Financial Position

- Procedural Compliance

- Reputation and Position in Industry

- Desire for Business

- Repair Service

- Attitude

- Packaging Ability

- Labor Relations Record

- Geographical Location

- Amount of Past Business [1]

\subsection{Various Supplier Selection Methods}

The supplier selection analyzes observed in the literature are summarized in Figure. [2]

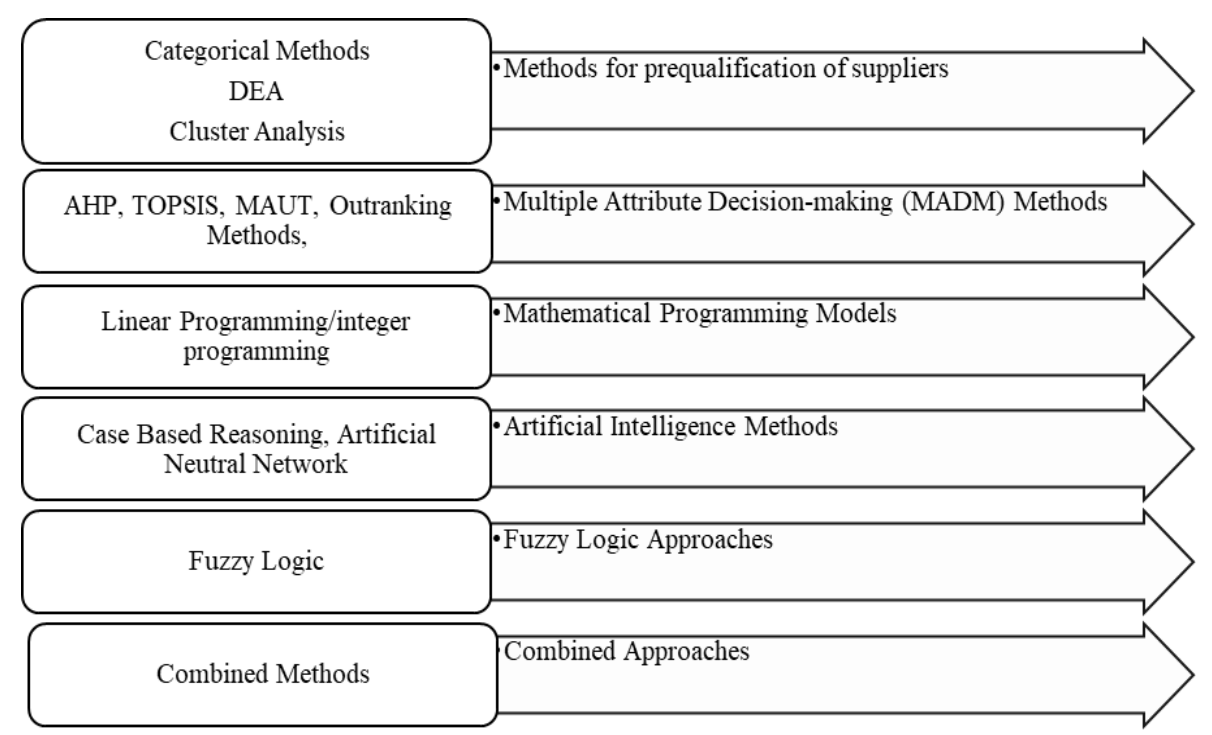

Figure 2: Various Supplier Selection Methods 


\subsubsection{Categorical Methods}

It is a qualitative model based on historical data. A number of criteria are used when evaluating suppliers. After evaluation, a score is given to the supplier. The evaluation process is clear and systematic. [3]

\subsubsection{Data Envelopment Analysis (DEA)}

It has two categories. One is efficient and the other is inefficient. Suppliers are evaluated according to outputs and inputs. This evaluation assumes $100 \%$ efficiency if a supplier cannot produce a string with a set of inputs if the other supplier produces it. [4]

\subsubsection{Cluster Analysis (CA)}

It is a basic method of statistics. It keeps a set of items in a set of sets so that the differences are minimal. Different clusters have the highest value. In this classification, the algorithm reduces a large supplier group to smaller subsets. [5]

\subsubsection{Analytical Hierarchical Process (AHP)}

There are actually too many criteria in choosing a vendor. At the same time, alternative evaluations are required. In this selection method, there are three different selection levels for targets, criteria and alternatives. It is a combination of two basic parts. The first consists of criteria and sub-criteria, while the second part observes the effects between items and clusters. [6]

\subsubsection{Technique for the Order Performance by Similarity to Ideal Solution (TOPSIS)}

It is another problem-solving technique. The closeness coefficient is assigned to all suppliers. TOPSIS is based on the best solution having the least distance from the ideal solution and the worst solution having the longest distance from the most negative. The ratings and weights of the factors are linguistic. [7]

\subsubsection{Multiple Attribute Utility Theory (MAUT)}

The advantage of this method is that it helps purchasing professionals to formulate strategies and overcome conflicting situations. [8].

\subsubsection{Outranking Methods}

This method allows solving multi-criteria problems. It is used to deal with uncertainty. It is not a very high-ranking model. [9]

\subsubsection{Integer Programming}

This method is the most traditional method. It is linear programming and the expression of variables with integer values. It greatly increases the problems to be modeled. Although the solution seems to be difficult when the number increases and requires different calculations, it is of great benefit when the optimum solution is reached in large design. [10,11] 


\subsubsection{Case-Based-Reasoning (CBR) Systems}

It is based on artificial intelligence. It is a difficult decision-making system. There is a database with useful information from similar and previous cases. It is still new. Few systems are used in the world however. [12]

\subsubsection{Artificial Neural Network (ANN)}

It saves money and time. Its weakness is that it requires software developers and specialist personnel. [12]

\subsubsection{Combined Approaches/ Hybrid Methods}

Degraeve and Roodhoft [13] combined the mathematical model and TCO. Ghodsupour and O'Brien [14] combined the AHP and linear programming model. Sanayei et al. [15] established an effective model with MAUT and LP. Shyur [16] used both ANP and TOPSIS effectively. Boran [17] used fuzzy logic approach with TOPSIS. All models have been used with each other.

In this work, the integer programming model was used, because it is difficult to obtain a plenty of data for statistical analyses. Also, there are certain constraints for the model and it is necessary to have a specific objective function and it was aimed to make an optimization. Moreover, it is thought that one formulation may quickly lead to optimal solutions, while the other methods may take an excessively long time to solve.

\section{Mathematical and Integer Programming Model}

\subsection{Basic Assumptions and Explanations of Inputs for Mathematical Model}

> Payment period is defined as the period taken by the company for making payments to its suppliers. In the current model, last day of the payment period is used for the net present value calculation.

$>$ There is a transportation price paid to transport agency. This price also has a payment period. Similarly, last day of the transportation costs' payment period is used for the net present value calculation.

$>$ In this model, demanded data for sample parts are obtained from a firm's older procurement database. For future purchasing, data may change, however, in this model it is believed to be useful for comparing between the new model and the old model.

$>$ Another complexity exists in penalty for delaying project due to delay in supply parts. This is calculated according to the contract between MITAS and MITAS's clients. Although, clients may not request delay cost for related project due to the standard contract procurement or because it may not be too critical for them. In this Project, it is evaluated as penalty costs assessed for each procurement.

$>$ The other important point is scrap price and scrap decision. It can be predicted before the procurement by asking planning department in MITAS. In this model, if surplus product is not used in the near future, it can be considered to be sold to scrap dealers. Additionally, in case surplus occurs in amount and if there may the possibility of usage in the near future, then, holding 
cost may be neglected because of the fact that usage occurs utmost in a month and MITAS has a large storage capacity area for keeping parts.

$>$ Considering the fact that, products which MITAS purchases have unique lengths. MITAS can shorten the products which are longer than the required height, and also considering the fact that, some firms may offer lower prices for their product which is longer than the required product compared to other firms' that offer higher prices for their shorter product. In case a firm gives offer to a shorter amount than our demand, it will not included in the optimization model, because it is impossible to convert the material to demanded lengths.

$>$ In the current model, factors affecting the price of the product are specified with a net present value. Other factors like penalty for delaying project due to delay in supply part and surplus amount of the product are shown in an objective function. Each firm has the maximum and minimum order quantity and these are shown as constraints in the mathematical model.

Model is run for a single product in an aim to reach an easy and practical solution. Users are able to separate the material that it is to be executed easily from the list, which can provide a practical solution for them.

Model gives which firm should supply to an exact material and which quantity should be supplied.

Indices:

$\mathrm{j}$ : supplier $\quad \mathrm{j}=1, \ldots, \mathrm{J}$

\section{Parameters:}

$p_{j}$ : Per ton product price of supplier $\mathrm{j}$

$p p_{j}$ : Daily basis payment period of supplier $\mathrm{j}$

ir: Daily interest rate

$t c_{j}$ : Unit transportation cost of firm $\mathrm{j}$

tcpp $_{j}$ : Daily basis transportation cost payment period of firm $\mathrm{j}$

$c$ : Per ton scrap price ( Per ton scrap price doesn't change with product type.)

$k$ : Scrap or holding criteria. It must be 1 or 0 .

$>$ If it is 1 , this means that surplus product won't be used in the near future. This can be sold.

$>$ If it is 0 , this means that product should not be sold, it will be used in the near future.

$q_{j}$ : Quality score for firm j. (Quality score is determined according to the past performance records taken from quality department.)

qa: Required quality score

$>$ Total quality score for firm $\mathrm{j}$ must be larger than or equal to acceptable quality score. This elimination is done before execution of model. If quality score of firm is lower than the acceptable quality score, this firm cannot be included in the inputs.

$u_{j}$ : The maximum order quantity for supplier $\mathrm{j}$

$a_{j}$ : The minimum order quantity for supplier $\mathrm{j}$

$d$ : Demand (ton basis).

$l_{j}$ : Lead time of supplier $\mathrm{j}$ (in days)

$b$ : Required Date (in days) 
$t_{j}$ : Delay time of firm $\mathrm{j}$. When $\mathrm{b}$ is the acceptable lead time, If $\mathrm{b} \geq \mathrm{lj}$, this is assigned $0 \mathrm{If} \mathrm{b}<\mathrm{lj}$, this is assigned lj-bi (in days). $t_{j}$ is calculated with using excel before execution of the model.

$g$ : Delay cost (per ton per day)

$n p v_{j}$ : Net Present Value of firm j (per ton)

\section{Calculation of the net present value for a sample firm:}

In order to calculate the net present value for one part of any firm; price, payment period for material cost, lead time, required length, length of the material firm can provide, transportation cost, payment period for transportation cost should be considered in the following manner.

$$
n p v_{j}=\left(\left(1+\left(\frac{v-w}{w}\right)\right) *\left(\frac{p_{j}}{(1+i r)^{\left(p p_{j}+l_{j}\right)}}+\frac{t c_{j}}{\left.(1+i r)^{\left(t c p p_{j}+l_{j}\right)}\right)}\right)-\left(c *\left(\frac{v-w}{w}\right)\right)\right.
$$

\begin{tabular}{|c|c|c|c|c|c|c|c|}
\hline$p_{j}$ & $t c_{j}$ & $p p_{j}$ & $t c p p_{j}$ & ir & c & $v$ & w \\
\hline $\begin{array}{l}\text {-Per ton } \\
\text { product price }\end{array}$ & $\begin{array}{l}\text { - Unit } \\
\text { transport } \\
\text { cost }\end{array}$ & $\begin{array}{l}\text {-Daily } \\
\text { basis } \\
\text { payment } \\
\text { period }\end{array}$ & $\begin{array}{l}\text {-Daily } \\
\text { basis } \\
\text { transport } \\
\text { cost } \\
\text { payment } \\
\text { period }\end{array}$ & $\begin{array}{l}\text {-Daily } \\
\text { interest } \\
\text { rate }\end{array}$ & $\begin{array}{l}\text {-Per ton } \\
\text { scrap } \\
\text { price }\end{array}$ & $\begin{array}{l}\text { •Given } \\
\text { length } \\
\text { of the } \\
\text { product } \\
\text { from } \\
\text { supplier }\end{array}$ & $\begin{array}{l}\text { - The } \\
\text { desired } \\
\text { length of } \\
\text { the } \\
\text { product }\end{array}$ \\
\hline
\end{tabular}

Figure 3: Explanations of Parameters in NPV Formula

Vendors may offer the material which has a length longer than the requested one. In this situation, excess quantity should be taken for providing the requested length. For example, requested length is 10 meter-10 pieces. If firms offer 12 meter-material, 12 meter-12 piece should be bought and each of them should be cut to 10 meter pieces in MITAS. After cutting these 12 pieces from 12 meter to 10 meter, surplus 2 meter can be sold as scrap. Considering the information given above, model presented in this project recommended as a calculation on the grounds that this 12 meter sometimes can be cheaper and cost effective than 10 meter materials.

In case firm gives offer to a shorter amount than our demand, it will not included in the optimization model, because it is impossible to convert the material to demanded lengths.

All criteria should be converted into a net present value for evaluating equal conditions, because lead time and time of maturity change in each firm. Actually, calculation of the present value of the sum of the money will ensure accurate comparisons for making accurate predictions of the total cost. As a result, $n p v_{j}$ is calculated with using excel before execution of the model. 


\section{Decision Variables:}

$X_{j}$ : The amount of product supplied from supplier $\mathrm{j}$

$Y_{j}$ : This is a binary variable. The value is encoded ' 1 ' if the firm is selected and encoded ' 2 ' if not. DT: The maximum of the delay period values given for each firm.

\section{The LP Model:}

$\operatorname{Min} \sum_{j=1}^{I} X_{j} * n p v_{j}-\left(\left(\sum_{j=1}^{I}\left(X_{j}\right)-d\right) * c * k\right)+D T * g$

Subject to;

$$
\begin{array}{ll}
d \leq \sum_{j=1}^{I} X_{j} & \\
Y_{j} * M \geq X_{j} & \text { for } \forall \mathrm{j} \\
u_{j} \geq X_{j} & \text { for } \forall \mathrm{j} \\
X_{j} \geq a_{j} * Y_{j} & \text { for } \forall \mathrm{j} \\
D T \geq t_{j} * Y_{j} & \text { for } \forall \mathrm{j} \\
X_{j} \geq 0 & \\
\hline
\end{array}
$$

\section{Objective Function:}

Obj. func. Given in (1) minimizes the total cost of the procurement. The objective function contains the product purchasing cost, which is the net present value coming from product price; transportation cost; date of maturity and length of the material. Also, objective function contains delay cost due to retardation of project that is related to the purchasing. If surplus amount of the product cannot be used in the near future, this amount can be sold as a scrap. Therefore, this affect the total cost negatively (1) Thus, the purpose of the model is to include the factor of selling the product as scrap if the firm gives order over the necessity due to the fact that firm's having a net present value, delay cost criterion and minimum order quantity. 


\section{Constraints:}

To begin with, the demand should be satisfied. (2). Secondly, if the firm is not selected, any amount of the product should not be taken. (3) Thirdly, there are upper limits of the amount of product that can be sent for each firm. (4) Next, there are lower limits of the amount of product that can be sent for each firm. Similarly, product given from the company must be greater than the lower limit. (5). Next, maximum delay time coming from all selected firms should be used (6) Also, the amount of product supplied from supplier j should not be negative. (7)

\section{Computational Study}

Main purpose is validation of the model and look to benefit from making decisions over the past. The mathematical model of the current project is run using gams program for 6 materials. Chosen materials are: 40-100 S275JR ANGLE; 100-120 S355J0 ANGLE; 150-160 S355J2 ANGLE; 180-200 S355J2 ANGLE; 100-H200 S275JR PROFILE and U200-U300 S355J2 PROFILE. The first number (100-200) is specified as the dimensional standard and the second part (S355J2) is assigned as the quality standard. In this project, 26 firms are taken as input running the corresponding materials. Since, it is time consuming to take offer from each supplier and since it is thought as unnecessary, data related to firms that had already proposed offers in the past projects, are used. The reason of utilization of the above presented 6 materials is that these materials are used by steel companies that produce electricity poles and lines frequently and it is available to reach data related to them. Considering the possibility of foreign firms that have alternative ways for transporting, these are included in our data as a different option of the same firm. 'Net present value' is calculated by using an excel formulation.

- In this computational study, 60 is taken as the minimum necessary quality score for evaluation. In other words, offers that are taken from firms having points below 60 quality score are not accepted as evaluative. If firms have had scores below sixty point in the last two years, these firms are removed from the list of the approved suppliers.

- $\quad$ For calculation npv, interest rate is taken yearly 4.5 percent in the dollar exchange. This interest rate is given from the bank working average with in the dollar exchange.

- The other important point is scrap price and scrap decision. It can be predicted before the procurement by asking planning department. In this model, if surplus product is not used in the near future, it can be considered to be sold to scrap dealers. Scrap decision named scrap criteria comes from planning department. Moreover, scrap price is 165 USD per ton for each material.

- If firm gives offer to a shorter amount than our demand, it will not included in the optimization model, because it is impossible to convert the material to demanded lengths.

For each firm, 'price payment period'; 'required lead time'; 'lead time of the firm'; 'transportation cost'; 'transportation cost payment period'; 'quality score'; 'required quality score scrap price'; 'scrap or holding criteria'; 'maximum order quantity'; 'minimum order quantity'; 'demand'; 'offer length'; 'delay cost' and 'net present value' are given in the tables separately.

6. Conclusion 


\section{Computational Study Summary}

Table 1: Value of obj. func and Performance Measures for 40-100 S275JR ANGLE

\begin{tabular}{|c|c|c|r|r|r|r|r|r|r|r|r|}
\hline $\begin{array}{c}\text { Product } \\
\text { Type }\end{array}$ & $\begin{array}{c}\text { Daily } \\
\text { interest } \\
\text { rate }\end{array}$ & $\begin{array}{c}\text { Required } \\
\text { Date (in } \\
\text { days) }\end{array}$ & $\begin{array}{c}\text { Required } \\
\text { quality } \\
\text { score }\end{array}$ & $\begin{array}{c}\text { Per } \\
\text { ton } \\
\text { scrap } \\
\text { price }\end{array}$ & $\begin{array}{c}\text { Scrap } \\
\text { or } \\
\text { holding } \\
\text { criteria }\end{array}$ & Demand & $\begin{array}{c}\text { Desired } \\
\text { length } \\
\text { of the } \\
\text { product }\end{array}$ & $\begin{array}{c}\text { Delay } \\
\text { cost } \\
\text { per } \\
\text { ton } \\
\text { per } \\
\text { day) }\end{array}$ & $\begin{array}{c}\text { Ex } \\
\text { Acquisition } \\
\text { Cost }\end{array}$ & $\begin{array}{c}\text { Value of } \\
\text { Objective } \\
\text { Fuction }\end{array}$ & Benefit \\
\hline $\begin{array}{r}40-100 \\
\text { S275JR } \\
\text { Angle }\end{array}$ & 0,000123 & 35 & 60 & 165 & 0 & 200 & 11000 & 4000 & $81.000 \mathrm{USD}$ & $81.000 \mathrm{USD}$ & 0 \\
\hline
\end{tabular}

Considering our 200 tons demand for 40-100 S275JR ANGLE material and considering 4000 USD as delay cost for a day, it is decided to purchase from the supplier 8 that has the optimum npv considering all the materials. The reason that the program yielded the aforementioned firm directly is accounted by the fact that the firm present no delay and provide the demanded length of the material. The total cost is calculated as 81.000 USD. It is found that even when net present value is not calculated, the same firm is yielded as the optimum firm. However, when net present value is calculated and transport cost and maturity period of the firm are included, the firm is verified as the optimum one. Demand is attained in this material exactly with yielding no surplus.

Table 2: Value of obj. func and Performance Measures for 100-120 S355J0 ANGLE

\begin{tabular}{|c|c|c|r|r|r|r|r|r|r|r|r|}
\hline $\begin{array}{c}\text { Product } \\
\text { Type }\end{array}$ & $\begin{array}{c}\text { Daily } \\
\text { interest } \\
\text { rate }\end{array}$ & $\begin{array}{c}\text { Required } \\
\text { Date (in } \\
\text { days) }\end{array}$ & $\begin{array}{c}\text { Required } \\
\text { quality } \\
\text { score }\end{array}$ & $\begin{array}{c}\text { Per } \\
\text { son } \\
\text { scrap } \\
\text { price }\end{array}$ & $\begin{array}{c}\text { Scrap } \\
\text { or } \\
\text { holding } \\
\text { criteria }\end{array}$ & Demand & $\begin{array}{c}\text { Desired } \\
\text { length } \\
\text { of the } \\
\text { product } \\
\text { in } \\
\text { mm) }\end{array}$ & $\begin{array}{c}\text { Delay } \\
\text { cost } \\
\text { (per } \\
\text { ton } \\
\text { per } \\
\text { day) }\end{array}$ & $\begin{array}{c}\text { Ex } \\
\text { Acquisition } \\
\text { Cost }\end{array}$ & $\begin{array}{c}\text { Value of } \\
\text { Objective } \\
\text { Fuction }\end{array}$ & Benefit \\
\hline $\begin{array}{c}100-120 \\
\text { S355J0 }\end{array}$ \\
ANGLE
\end{tabular}

Product type, daily interest rate, required date, required quality score, scrap price, scrap decision, desired length of the product, ex acquisition cost, value of objective fuction and benefit are shown above table. For this material in our project, the program run with 14 firms meeting determined criteria. Since it is difficult to supply the demanded material, 11 firms asked for their offers were not able to give an offer and 1 firm that does not meet our criterion value of 60 , is excluded from the program. For this material, the demanded amount is 250 tons, the demanded length is $10000 \mathrm{~mm}$ and delay cost is 3000 USD per day. Program yielded to the supplier 21 for the 100 tons of the 250 tons, and supplier 26 for the rest of the 150 tons (of the 250 tons). In the analysis of the net present values, it can be seen that, the lowest npv is obtained for supplier 26 followed by supplier 3. In ordinary purchases, 150 tons are supplied from supplier 26 and 100 tones are supplied from supplier 3. On the other hand, as delay cost is used as an input in our new model and it is known that supplier 3 has 21 days delay, supplier 21 is selected instead of this firm. The total cost is calculated as 114950 USD. It is obvious that, if purchase was done with past criteria, total amount would be 63000 USD leading a higher cost. Namely, delay cost criterion, prevented purchase from supplier 3. It can be inferred that, if firm supplier 26 had 
offered 250 tons as a maximum value, program would have yielded only this firm for all of the purchase amount.

Table 3: Value of obj. func and Performance Measures for 150-160 S355J2 ANGLE

\begin{tabular}{|c|c|c|r|r|r|r|r|r|r|r|r|}
\hline $\begin{array}{c}\text { Product } \\
\text { Type }\end{array}$ & $\begin{array}{c}\text { Daily } \\
\text { interest } \\
\text { rate }\end{array}$ & $\begin{array}{c}\text { Required } \\
\text { Date (in } \\
\text { days) }\end{array}$ & $\begin{array}{c}\text { Required } \\
\text { quality } \\
\text { score }\end{array}$ & $\begin{array}{c}\text { Per } \\
\text { ton } \\
\text { scrap } \\
\text { price }\end{array}$ & $\begin{array}{c}\text { Scrap } \\
\text { or } \\
\text { holding } \\
\text { criteria }\end{array}$ & $\begin{array}{c}\text { Desired } \\
\text { length } \\
\text { Demand the } \\
\text { product } \\
\text { (in } \\
\text { mm })\end{array}$ & $\begin{array}{c}\text { Delay } \\
\text { cost } \\
\text { per } \\
\text { ton } \\
\text { per } \\
\text { day }\end{array}$ & $\begin{array}{c}\text { Ex } \\
\text { Acquisition } \\
\text { Cost }\end{array}$ & $\begin{array}{c}\text { Value of } \\
\text { Objective } \\
\text { Fuction }\end{array}$ & Benefit \\
\hline $\begin{array}{r}150-160 \\
\text { S355J2 } \\
\text { ANGLE }\end{array}$ & 0,000123 & 56 & 60 & 165 & 1 & 150 & 9500 & 2500 & $74850 \mathrm{USD}$ & $74850 \mathrm{USD}$ & 0 \\
\hline
\end{tabular}

Product type, daily interest rate, required date, required quality score, scrap price, scrap decision, desired length of the product, ex acquisition cost, value of objective fuction and benefit are shown above table. For this material, the program run with 12 firms meeting determined criteria from the list of 26 firms. Since it is very hard to supply the demanded material, 14 firms were not able to give an offer for this material. For this material, the demanded amount is 150 tons, the demanded length is $9500 \mathrm{~mm}$ and delay cost is 2500 USD per day. Program yielded to supplier 3 for purchasing the total amount of the 150 tons. The reason that the program yielded to the mentioned firm is accounted by the fact that the firm has the lowest net present value and offer to provide the exact demanded length and amount of the material. More specifically, the results are consistent with previous ones confirming the accuracy of the model run. The total cost of the purchase is calculated as 74850 USD.

Table 4: Value of obj. func and Performance Measures for 180-200 S355J2 ANGLE

\begin{tabular}{|c|c|c|c|c|c|c|c|c|c|c|c|}
\hline $\begin{array}{c}\text { Product } \\
\text { Type }\end{array}$ & $\begin{array}{c}\text { Daily } \\
\text { interest } \\
\text { rate }\end{array}$ & $\begin{array}{c}\text { Required } \\
\text { Date (in } \\
\text { days) }\end{array}$ & $\begin{array}{c}\text { Required } \\
\text { quality } \\
\text { score }\end{array}$ & $\begin{array}{c}\text { Per } \\
\text { ton } \\
\text { scrap } \\
\text { price }\end{array}$ & $\begin{array}{c}\text { Scrap } \\
\text { or } \\
\text { holding } \\
\text { criteria }\end{array}$ & Demand & $\begin{array}{l}\text { Desired } \\
\text { length } \\
\text { of the } \\
\text { product } \\
\text { (in mm) }\end{array}$ & $\begin{array}{c}\text { Delay } \\
\text { cost } \\
(p e r \\
\text { ton } \\
\text { per } \\
\text { day) }\end{array}$ & $\begin{array}{c}\text { Ex } \\
\text { Acquisition } \\
\text { Cost }\end{array}$ & $\begin{array}{c}\text { Value of } \\
\text { Objective } \\
\text { Fuction }\end{array}$ & Benefit \\
\hline $\begin{array}{r}180-200 \\
\text { S355J2 } \\
\text { ANGLE }\end{array}$ & 0,000123 & 56 & 60 & 165 & 1 & 5 & 12000 & 1000 & 10470USD & 3300USD & 7170USD \\
\hline
\end{tabular}

Product type, daily interest rate, required date, required quality score, scrap price, scrap decision, desired length of the product, ex acquisition cost, value of objective fuction and benefit are shown above table.For this material in our project, the program run with 10 firms (from 26 firms) meeting our determined criteria. Considering the fact that it is difficult to supply the demanded material, and considering the minority of our demand and considering the fact that it may not be profitable for many firms to give an offer, 16 firms asked for their offers were not able to give an offer.

For this material, our demanded amount is 5 tons, our demanded length is $12000 \mathrm{~mm}$ and our delay cost in this project is 1000 dollars per day. Program suggested the firm supplier 25. For the 100 tons of the 250 tons, and supplier 26, for the rest of the 150 tons (of the 250 tons). In the analysis of the net present values, 
it can be seen that, the lowest npv is obtained for supplier 26 followed supplier 3. In fact, when net present values are considered, the material is suggested to be purchased from supplier 21 and followed by supplier 22 in the event of any impossibility of purchasing.

However, since, the minimum order quantity for supplier 21 is 15 tons and supplier 22 has 7 days delay, program selected supplier 25 which provides the optimum result. The total cost is found to be 3300 USD in this purchase. Program saved 7170 dollars as supplier 22 was selected in the past purchases.In addition, Program saved 5970 USD as supplier 21 was selected in the past purchases because of purchasing 15 ton instead of 5 ton.

Table 5: Value of obj. func and Performance Measures for 100-H200 S275JR PROFILE

\begin{tabular}{|c|c|c|c|c|c|c|c|c|c|c|c|}
\hline $\begin{array}{c}\text { Product } \\
\text { Type }\end{array}$ & $\begin{array}{c}\text { Daily } \\
\text { interest } \\
\text { rate }\end{array}$ & $\begin{array}{c}\text { Required } \\
\text { Date (in } \\
\text { days) }\end{array}$ & $\begin{array}{c}\text { Required } \\
\text { quality } \\
\text { score }\end{array}$ & $\begin{array}{c}\text { Per } \\
\text { ton } \\
\text { scrap } \\
\text { price }\end{array}$ & $\begin{array}{c}\text { Scrap } \\
\text { or } \\
\text { holding } \\
\text { criteria }\end{array}$ & Demand & \begin{tabular}{|} 
Desired \\
length \\
of the \\
product \\
(in \\
mm)
\end{tabular} & $\begin{array}{c}\text { Delay } \\
\text { cost } \\
\text { (per } \\
\text { ton } \\
\text { per } \\
\text { day) }\end{array}$ & $\begin{array}{c}\text { Ex } \\
\text { Acquisition } \\
\text { Cost }\end{array}$ & $\begin{array}{c}\text { Value of } \\
\text { Objective } \\
\text { Fuction }\end{array}$ & Benefit \\
\hline $\begin{array}{r}100-\mathrm{H} 200 \\
\text { S275JR } \\
\text { PROFILE }\end{array}$ & 0,000123 & 42 & 60 & 165 & 1 & 150 & 11500 & 5000 & 64800USD & 63900SD & 900USD \\
\hline
\end{tabular}

For this material, the program run with 14 firms (from 26 firms) meeting our determined criteria. As, it is difficult to supply the demanded material, and as the material is a profile one, 12 firms were not able to give an offer. For this material, our demand is 150 tons, our demanded length is $11500 \mathrm{~mm}$ and our delay cost in this project is 5000 USD per day. Program presented supplier 22, for purchasing the total amount of the demanded material. When npvs are regarded, it can be seen that, the npv of the firm supplier 22 is the lowest one and at first glance it may be considered to be reasonable to select supplier 15 that offers our demanded length. Nevertheless, program, as an optimum output, signified supplier 22 which offers a length longer than our demanded amount, as the surplus amount can be sold to a wrecker.

The total cost is found to be 63900 USD in this purchase. If the material was purchased from supplier 15 as done in the previous purchases, the cost would be 64800 USD. The current purchase resulted in a more profitable and optimum output.

Table 6: Value of obj. func and Performance Measures for U200-U300 S355J2 PROFILE

\begin{tabular}{|c|c|c|c|c|c|c|c|c|c|c|c|}
\hline $\begin{array}{c}\text { Product } \\
\text { Type }\end{array}$ & $\begin{array}{c}\text { Daily } \\
\text { interest } \\
\text { rate }\end{array}$ & $\begin{array}{c}\text { Require } \\
\text { d Date } \\
\text { (in days) }\end{array}$ & $\begin{array}{c}\text { Require } \\
\text { d quality } \\
\text { score }\end{array}$ & $\begin{array}{c}\text { Per } \\
\text { ton } \\
\text { scra } \\
p \\
\text { price }\end{array}$ & $\begin{array}{c}\text { Scrap } \\
\text { or } \\
\text { holdin } \\
\quad g \\
\text { criteria }\end{array}$ & $\begin{array}{c}\text { Deman } \\
d\end{array}$ & \begin{tabular}{|c|} 
Desired \\
length \\
of the \\
produc \\
$t($ in \\
mm $)$ \\
\end{tabular} & $\begin{array}{c}\text { Dela } \\
\text { y cost } \\
(\text { per } \\
\text { ton } \\
\text { per } \\
\text { day) } \\
\end{array}$ & $\begin{array}{c}E x \\
\text { Acquisition } \\
\text { Cost }\end{array}$ & $\begin{array}{c}\text { Value of } \\
\text { Objective } \\
\text { Fuction }\end{array}$ & Benefit \\
\hline $\begin{array}{r}\text { U200- } \\
\text { U300 } \\
\text { S355J2 } \\
\text { PROFIL } \\
E\end{array}$ & $\begin{array}{r}0,00012 \\
3\end{array}$ & 56 & 60 & 165 & 1 & 200 & 12000 & 1500 & $\begin{array}{r}\text { 114800US } \\
\text { D }\end{array}$ & $\begin{array}{r}\text { 111300US } \\
\text { D }\end{array}$ & $\begin{array}{r}3500 \mathrm{US} \\
\mathrm{D}\end{array}$ \\
\hline
\end{tabular}


For this material, the program run with 10 firms (from 26 firms) meeting our determined criteria. As, it is difficult to supply the demanded material, and as the material is a profile one, 15 firms were not able to give an offer and one firm excluded from the program because they offered a shorter amount than our demanded length.

For this material, our demand is 200 tons, our demanded length is $12000 \mathrm{~mm}$ and our delay cost in this project is 1500 dollars per day. Model indicated supplier 11 for purchasing the total amount of 200 tons. When npvs are examined, it can be seen that, the npv of the firm supplier 22 is the lowest one. Nonetheless, this firm has a drawback of 7-day delay. Eventually, despite the delay cost, supplier 11, appeared as the lowest one and scored better than the nearest firm.

The total cost is found to be 111300 USD in this purchase. If the material was not purchased from the selected firm and instead of was purchased from the nearest rival supplier 11, the total cost would be 114800 USD, leading to higher cost.

\section{CONCLUSION}

The main aim of this project is to present a model that provides criteria for accurate selection of suppliers and analyses methods of this selection procedures yielding to the most cost effective output. Accordingly, literature execution was made and integer program method was selected. Six samples were dissolved by creating a model. The model is based on the information that factors such as 'time value of money'; 'profit or loss of delay to the firm'; and 'procurement of material that has a length longer than the requested one may be profitable' are analyzed parameters and appraised in previous purchases of the aforementioned firm. Finally, the results were evaluated based on past results. Results presented in the 'COMPUTATIONAL STUDY' section propose that the model and optimization procedures in our project may suggest a financial profit. It can be predicted that this model can provide profit for the firm also in the large scale. In a similar vein, this project may be enhanced and contribute to a firm by healing the future growth targets of the incremental costs of the firms' purchases. As a result, it is promising to be presented to executives. In addition, the complete part of the program may be written as a $\mathrm{C}$ program, with an interface, which compromises a program that can be used in the purchasing procedures of the firm after a sound analysis of the pros in the short and long term. 


\section{References}

[1] Arslan, G.; Kivrak, S.; Birgonul, M.; Dikmen, I. Improving sub-contractor selection process in construction projects: Web-based sub-contractor evaluation system (WEBSES). Autom. Constr. 2008, 17, $480-488$.

[2] Lam, K.C.; Tao, R.; Lam, C.K. A material supplier selection model for property developers using Fuzzy Principal Component Analysis. Autom. Constr. 2010, 19, 608-618.

[3] Maggie C.Y.T. and Tummala, V.M.R. "An application of the AHP in vendor selection of a telecommunications system”, Omega, 29 (2001) 171-182.

[4] Hill, R.P. and Nydick, R.L., "Using the Analytic Hierarchy Process to structure the supplier selection procedure", International Journal of Purchasing and Materials Management 28 (2) (1992) 31-36.

[5] Hinkle, C.L., Robinson, P. J., Green, P. E., "Vendor evaluation using cluster analysis", Journal of Purchasing 5 (3) (1969) 49-58.

[6] Saaty, T. L., “Fundamentals of Analytical Process”, ISAHP 1999, Kobe, Japan, Aug 12 - 14, 1999.

[7] Elanchezhian, C., Vijaya Ramnath, B., and Dr. R. Kesavan, "Vendor Evaluation Using Multi Criteria Decision Making”, International Journal of Computer Applications 5 (9) (2010) 0975 - 8887.

[8] Saaty, T. L., "Decision Making with Dependence and Feedback: TheAnalytic Network Process", RWS Publications, Pittsburgh, P.A. (1996).

[9] Ellram, Lisa M. "Total Cost of Ownership: An analysis approach for purchasing" International Journal of Physical Distribution \& Logistics Management. 25(8) (1995) 4-23.

[10 ] San, C.J. Contractor selection using multicriteria decision-making methods. J. Constr. Eng. Manag. 2011, 138, 751-758.

[11] Bross, M.E. and Zhao, G. "Supplier selection process in emerging markets - The Case Study of Volvo Bus Corporation in China", School of Economics and Commercial Law Göteborg University (2004).

[12] Faez, F., Ghodsypour, S. H. and O’Brien, C., "Vendor selection and order allocation using an integrated fuzzy case-based reasoning and mathematical programming model", International Journal of Production Economics, 121(2)(2009), 395-408.

[13] Degraeve, Z. and F. Roodhoft "Effectively Selecting Suppliers UsingTotal Cost of Ownership," Journal of Supply Chain Management, 35(1) (1999) 5-10.

[14] Ghodsypour S. H., O’Brian C. "A decision support system for supplier selection using an integrated analytic hierarchy approach and linear programming”, Int. J. Prod. Econ., 56/57(1998) 199-212.

[15] Sanayei, A., Mousavi, S.F. Abdi, M.R. and Mohaghar, A., "An integrated group decision-making process for supplier selection and order allocation using multi-attribute utility theory and linear programming", Journal of the Franklin Institute, 345(2008) 731-747. 
[16] Shyur, H.J. and Shih, H.S., “A hybrid MCDM model for strategic vendor selection”, Mathematical and Computer Modeling, 44(2006) 749-761.

[17] Boran, F.E., Genc, S., Kurt, M. and Akay, D., “A multi-criteria intuitionistic fuzzy group decision making for supplier selection with TOPSIS method", Expert Systems with Applications, 36 (2009) 11363 11368 